\title{
Monocyte Chemotactic Protein 1 Measurement
}

National Cancer Institute

\section{Source}

National Cancer Institute. Monocyte Chemotactic Protein 1 Measurement. NCI

Thesaurus. Code C82025.

The determination of the amount of monocyte chemotactic protein 1 present in a sample. 